\title{
Survival at the frontier of Holy War: political expansion, crusading, commerce and the medieval colonizing settlement at Biała Gora, North Poland
}

Article

Accepted Version

Sawicki, Z., Pluskowski, A., Brown, A., Badura, M., Shillito, L.M., Makowiecki, D., Zabilska-Kunek, M. and Seetah, K. (2015) Survival at the frontier of Holy War: political expansion, crusading, commerce and the medieval colonizing settlement at Biała Gora, North Poland. European Journal of Archaeology, 18 (2). pp. 282-311. ISSN 1461-9571 doi:

https://doi.org/10.1179/1461957114Y.0000000071 Available at https://centaur.reading.ac.uk/36628/

It is advisable to refer to the publisher's version if you intend to cite from the work. See Guidance on citing.

To link to this article DOI: http://dx.doi.org/10.1179/1461957114Y.0000000071

Publisher: Maney

All outputs in CentAUR are protected by Intellectual Property Rights law, including copyright law. Copyright and IPR is retained by the creators or other copyright holders. Terms and conditions for use of this material are defined in the End User Agreement. 


\section{www.reading.ac.uk/centaur}

\section{CentAUR}

Central Archive at the University of Reading

Reading's research outputs online 


\section{Introduction}

The term 'colonisation' is routinely used by archaeologists and historians working with medieval societies in the Baltic Sea region. This refers to the establishment of settlements following the movement of people into landscapes, previously unoccupied by these distinct ethno-political groups (Piskorski 2002). In the southern Baltic, episodes of colonisation were accompanied by processes of military conquest, political subjugation and religious conversion. The most striking symbol of this process surviving today is the red brick castle at Malbork in north Poland (formerly Marienburg in Prussia). The largest fortified structure constructed in medieval Europe, it represents the end point of an extended process of colonisation of the Lower Vistula valley which began in the late Viking Age; the tenth to eleventh century (fig. 1). Early written sources described this region as the borderland between eastern Pomerania (Pomerelia), and the adjacent territories of Pomesania and Pogesania (fig. 2). In the Viking Age, Pomeranian Slavic settlements spreading across the Vistula floodplain and its eastern tributary, the Nogat, eventually gave way to villages and strongholds associated with Prussians, a completely different ethnic group (Haftka 1987; Jagodziński 2004). Scandinavians also formed an important component in this multi-ethnic landscape, particularly associated with the emporium of Truso (Jagodziński 2010). By the end of the tenth century, the political reach of the emerging Polish Christian state had extended to this region. Gdańsk, already established as a major settlement by the mid-ninth century (Paner 1998-1999), eventually replaced Truso as the main emporium on the other side of the fenlands, and its dukes, allied with the Polish crown, increasingly flexed their political control over this borderland through strongholds. During the twelfth century, borderland tensions increased as Polish magnates raided Prussian lands, whilst Prussian incursions reached as far as Gdańsk itself. Local conflicts were replaced by a papallysanctioned holy war led by the Teutonic Order, and by 1233 crusading armies had reached the Lower Vistula. Half a century later, Prussian tribal lands had been conquered and reorganised into a theocratic state governed by the Teutonic Order and its episcopal allies. During the crusading period the Prussian territory of Pomesania became organised into two commanderies run by the Order's convents in Zantyr and Christburg. In 1309 the Teutonic Knights relocated their headquarters from Venice to Prussia and the fenland frontier became the heartland of their Ordensland, with the castle of Marienburg at its centre.

The development of the early medieval Polish state has been extensively investigated by archaeologists (Buko 2008; Urbańczyk 2008), although our understanding of the second and more profound phase of colonisation, following the crusades, has been dominated by historical sources (Biskup et al. 2009). More recently this situation has begun to change, with palaeobotanical studies identifying the impact of the two broad phases of colonisation on the vegetation within the vicinity of Malbork (Brown and Pluskowski 2011). Whilst Pomeranian sites east of the Nogat appear to have been abandoned before the crusades (Jagodziński 2004), with a visible, albeit in some cases short, hiatus between the early and later medieval settlement pattern (Haftka 1987: 41); a site occupied during this transitional period has been identified to the north of the village of Biała Gora (formerly Weißenburg), c. $18 \mathrm{kms}$ southwest of Malbork (Sztum county, Pomeranian voivodeship). It represents a unique example of an excavated medieval rural colony in the Vistula borderlands, and from 1309 situated within the core of the Ordensland. With no above-ground remains, it has not been affected by subsequent building development or the growth of woodland, although the western parts of the site were destroyed following various hydrological modifications of the Nogat's course. A summary of results from the excavations and associated fieldwork at Biała 
Góra (site 3) has recently been published (fig. 3; Pluskowski et. al 2014). The purpose of this paper is to situate the colony within a more detailed landscape context.

\section{Colonies of the early medieval borderland and the ideology of holy war}

The expansion of the Polish Piast state resulted in the military conquest of Pomerelia in the 960s. The stronghold constructed in Gdańsk at the end of the tenth century coincides with the documented political influence of the Piasts, with neighbouring centres such as Wolin declining at this time (Buko 2008: 198-199). Although the town's population was nominally Christianised by St. Adalbert's documented mission in 997, it is clear that pre-Christian practices continued. In fact, Polish authority over Pomerelia was contested throughout the eleventh century and only finally secured by Bolesław III in the 1120s. It was accompanied by the development of an ecclesiastical infrastructure and missionary activity, particularly associated with Otto of Bamberg. By this time Pomerelia had developed a visible political identity, centred on the ducal stronghold in Gdańsk and its lords became increasingly confident, inter-dependent rulers from the second half of the twelfth century (Paner 1997: 277-279). The town became the dominant regional centre in Pomerelia and its hinterland was significantly developed as requirements for fuel, timber, agrarian products and livestock dramatically increased; at the same time, certain expanses of woodland appear to have been managed (Latałowa et al. 2007; Makowiecka et. al. 1998).

The dukes of Gdańsk supported a process of eastwards colonisation across the Vistula fenlands. This consisted of establishing strongholds and open settlements, with authority devolved to local elites, the most important of which bore the title of castellan with jurisdiction over defined territories (Rajman 2009). On the eastern side of the Lower Vistula valley, known strongholds in the twelfth century were strung out on the higher ground east of the floodplain within the vicinities of Węgry, Jordanki, Kalwa, Baldram-Podzamcze, Kwidzyn, further south at Łodygowo, before Grudziądz marked the start of a cluster in the Kulmerland centred on the complex at Kałdus (Jagodziński 1997; Chudziak 2003; Poliński 2003; Janowski 2007). On the coast, a stronghold may have existed at Przemysław with the location re-used by the Teutonic Order in 1242, although this has not been verified archaeologically (Jagodziński 1997: 30-31). Between them, the strongholds controlled all traffic along this final stretch of the river and its tributaries. The highest concentration of settlement activity in the Pomerelia/Pomesania borderlands has been noted from within the vicinity of the Forest of Sztum, and along the eastern escarpments overlooking the River Nogat (fig. 3), whilst the easternmost extent of Pomeranian settlement appears to be the valley of the River Dzierzgoń and Lake Drużno. This has been determined primarily by differences in ceramics separated into Slavic (i.e. found in Pomerania and the Kulmerland) and Prussian wares. Actual settlements with identifiable buildings are rare; the majority of 'sites' documented by the AZP (Archeologiczne Zdjęcie Polski) and Adalbertus programmes consisted of ceramic scatters (Chudziak 2006), which could relate to household waste dumped on fields, as much as places of occupation.

The use of ethnically associated ceramic typologies to define the Prussian-Slavic borderlands must be treated with caution, particularly given the use of 'Slavic' ceramics within sites associated with early medieval Prussians (Wróblewski 2006), or the designation of Scandinavian 'colonies' in the south-eastern Baltic. The relationship between Slavic and Prussian ceramic traditions remains to be understood more fully, and the question of accurate dating demands particular attention (Szczepański 2010: 292). The predominant presence of Scandinavians in the harbour district of Janów Pomorski (Truso), identified on the basis of 
concentrations of material culture, has been contrasted with 'locally produced' ceramics linked to Prussian and east Slavic groups, perhaps even inhabiting separate areas of the emporium (Auch et. al. 2012: 151). The differences between ceramic clusters assigned with Slavic and Prussian sites in the southern Baltic are technological and stylistic, and are paralleled by other distinctive material practices, particularly burial rites (Okulicz-Kozaryn 1997). In the Vistula fenlands, detailed toponymic studies have also contributed to an understanding of the ethno-topography of the borderland in the thirteenth century (Górnowicz 1980; Dlugokęcki 1992; Kawiński 2011:125).

This exceptional site appears to be a point of convergence between eastward moving Slavs and westward moving Prussians until the eleventh century, dispersing from the adjacent Prussian territory of Pogesania (Powierski 2003: 117). Given our understanding of the castellany system and the distribution of political centres in the more intensively studied Kulmerland, the presence of strongholds ought to provide a better indicator of more stable settlement areas. After the abandonment of Truso, Pomeranian colonists appear to have settled deep within the borderland territory. From the first quarter of the thirteenth century it is referred to as Pomesania, by which time it was associated with Prussians (Powierski 2003: 119). The majority of 'sites' between the Forest of Sztum and Lake Drużno are ceramic clusters and are unlikely to reflect the true number of settlements, whilst the dating of pottery to the 'thirteenth century' requires more detailed verification. Depending on which side of the crusading period this falls on makes a pivotal difference to understanding their cultural context. However, the absence of clearly identifiable Pomeranian strongholds in this region is striking and suggests a more unstable settlement pattern existed between the eleventh and thirteenth centuries (fig. 3, aft. Jagodziński 1997).

The western edges of an archaeologically visible Prussian settlement can be seen in two macro-landscapes: around Elbląg, the later site of the Teutonic Order's convent and town of Elbing, and around Dzierzgon, the later site of the convent of Christburg and its associated town. In the case of the former, almost all activity appears to have been situated to the east and north on the edges of the alluvium. In the vicinity of Dzierzgon, a quantity of wheelthrown ceramics was discovered during excavations in the 1930s and field walking in 1979, dated from the eleventh to thirteenth century and identified as Slavic (Jagodziński 1997:174175). Excavations at the Order's later castle nearby uncovered the remains of a wooden tower dating to the second decade of the eleventh century, most likely part of a Prussian stronghold complex. Its destruction by fire has been tentatively linked to the documented incursions of Polish armies (Pawłowski 2003: 414). Given the coarse resolution of the ceramic dating, as well as the problems of ethnic identification, it is entirely possible this series of sites represents successive Pomeranian and Prussian settlements, or alternatively evidence for the Prussian adoption/use of wheel-thrown ceramics. Within a $10 \mathrm{~km}$ radius of Dzierzgoń, confidently identified Pomeranian ceramics dated from the eleventh to thirteenth century have only been reported at two sites, whilst the majority of finds have not been assigned to any particular ethnic group. Strongholds within the vicinity have been more readily identified as Prussian. Around $7 \mathrm{kms}$ to the north-west of Dzierzgoń, Pomeranian ceramics have been found at Chojty and Trankwice, dated to the twelfth to thirteenth centuries, whilst c. $14 \mathrm{kms}$ to the south of Dzierzgon, identifiable Pomeranian material culture with comparable date ranges has been found within the vicinity of Lubowny Małe, although there are no confidently identified Pomeranian strongholds in this area (Jagodziński 1997). Yet whilst the Prussian strongholds in this region were abandoned or destroyed by the mid-thirteenth century, the population that survived the crusades appears to have persisted within the 
commandery of Christburg until the fifteenth century (Powierski 2003: 120), albeit with little archaeological visibility to date.

The first documented Prussian attack on Pomerania, which destroyed the monastery at Oliwa, took place in c. 1226. However, the abandonment of sites across the western and southwestern borderlands is suggestive of military instability already from the later twelfth century. Polish hagiographers noted an increased aggressiveness amongst the Prussians from the 1160s following a series of failed Polish military incursions, and reprisals are also documented following the short-lived crusade of 1218, into the 1220s (Śliwiński 2004: 55, 61). It is generally accepted that changes in the political organisation of the Prussian tribes were accompanied by militaristic expansion at this time. Whilst the presence of sporadic Prussian material culture in the Lower Vistula valley does not provide any tangible evidence of settlements (e.g. at Malbork), it corresponds to the perception of this entire region as Pomesania (i.e. occupied by Prussians) by the time its borders are documented by the Teutonic Order (Powierski 2003: 119). In turn, Pomeranian strongholds with clear evidence of destruction representing their final phase of occupation, such as the one at Radzyn Chełmiński in the Kulmerland (Chudziak 1994; see also Poliński 2003), and the less welldated stronghold at Kalwa (Haftka 2010: 92-93), have been tentatively linked to the documented trend in Prussian attacks. Indeed, the final occupation phases of the majority of settlement sites that do not continue into or beyond the thirteenth century (bearing in mind the coarse resolution of the ceramic typology) are regularly interpreted in terms of conflict between Prussian and Pomeranian settlers. The most striking tensions were religious, perhaps because they were inextricably tied to political allegiances.

\section{Missionary landscapes}

Whether the Prussian communities in the Lower Vistula borderlands were Christianised, as some have suggested, remains a moot point (Śliwiński 2004: 60). Pomeranian expansion certainly did have a striking religious dimension, echoing the construction of a sacro-political geography within the Piast state (Wiszewski 2010: 437). Abbeys in the heartlands of this state began to play important roles in the management of the Lower Vistula trade route, linking the Pomeranian strongholds with Gdańsk and the Baltic coast (Powierski 2001: 161). Some became actively involved in missionary activity targeting the neighbouring Prussian tribes, particularly the Cistercian abbey of Łekno and subsequently Oliwa (Śliwiński 2004). Evangelising was reinforced, perhaps even overshadowed, by institutions associated with the crusading movement. Three Hospitaller houses were also founded within the vicinity by the end of the twelfth century: at Starogard, Lubiszewo and Skarszewy. The Spanish Knights of Calatrava maintained a house at the Vistula crossing in Tymawa, although the date of its foundation remains debated. Unfortunately there is no evidence to indicate whether these military order communities were engaged in active crusading or other roles, including the provision of economic support (Gładysz 2012: 118-120). The sponsorship of the military orders to secure and manage this borderland follows a trend established in the Holy Land, and one that would eventually result in the consolidation of the Teutonic Order's theocratic state in Prussia by the late thirteenth century.

However, the presence of the military orders can also be linked to the proliferation of an ideology of holy war in the borderlands; touchstones for participation in the broader crusading movement and a means of framing military incursions against the Prussians. In the south-eastern Baltic, missionary, military and political agendas went hand in hand, although formal crusades against the Prussians were not endorsed by the papacy until 1217 
(Fonnesberg-Schmidt 2007: 138). Missionary activity appears to have been more successful in the south-western frontier regions of Pomesania and Lubawia Land (Gładysz 2012: 178, note 12), than in the Vistula fens. Here, the efforts of the first Bishop of Prussia - a Cistercian monk named Christian - are associated with a missionary outpost at Santir (Zantyr) granted to the Cistercians c. 1214 (Pollakówna 1967), which may relate to activities at the site of Biała Góra 3 (see below). The local military order ratified by the papacy in 1228 - the Knights of Dobrin - may even have maintained a garrison in Santir. A Norbertine parish is also documented at Postolin in 1236, on the eastern side of the Forest of Sztum. Indeed, the church here is designated for rebuilding within the Treaty of Christburg in 1249 (Szczepański 2013: 22). The lack of information on this early missionary activity in Dusburg's Chronicle can be explained by the political tensions between Bishop Christian and the Teutonic Order, and the struggle for control of the crusading enterprise (Haftka 2010: 144). The dominating role of religious institutions in the Vistula fenland frontier, particularly in the first decades of the thirteenth century, may reflect aspirations to create an ecclesiastical state in Prussia, inspired by the successes of crusading in Livonia (Śliwiński 2004: 59). Within a decade of the onset of the Prussian Crusade, Bishop Christian had been ousted and holy war and colonisation became the monopoly of the Teutonic Order.

The landscape encountered by the Teutonic Order during five decades of crusading in Prussia (1230-1283) is not easy to reconstruct. Historians have long debated questions of chronology and the changing geography of the borderland during the crusading period (see Powierski 2001; Szczepański 2011). Archaeologists, adopting a landscape approach, have also sought to precisely map the abandonment of settlements and the foundation of new colonies. At a few sites there is evidence for the continuation of occupation, particularly where Teutonic Order bracteates and greyware ceramics have been recovered. These include the final phase of Kałdus (Chudziak, 2003: 179) and the settlement complex around Gniew (Powierksi 2001: 166), although site re-locations were the norm during the early decades of the crusading period. Between the Nogat and Dzierzgoń rivers, archaeological evidence for Pomeranian activity into the crusading period is extremely limited. The best known example, to date, of a settlement with a transitional period of occupation is represented by the site adjacent to the village of Biała Góra (Pluskowski et al. 2014).

\section{Shifting frontiers and the vicissitudes of settlement in the Biała Góra macro-region}

The highest concentration of Pomeranian settlement, found in the vicinity of the Forest of Sztum, may have been organised from the stronghold and associated settlement at Węgry. The presence of military elite at the site is suggested by finds of weapons and two spurs (fig. 4). The site was occupied from c. 1025, and the pollen profile from a core taken $5 \mathrm{kms}$ to the north-east indicates deforestation and the expansion of the cultivated land during the eleventh and twelfth centuries (Brown and Pluskowski 2011). Interestingly, tentative evidence for local social volatility is represented by a hoard found between nearby Gosciszewo and Wielbark, consisting of coins and two silver beads along with the remains of the probable ceramic container, dating to the tenth/eleventh century (Jagodziński 1997). Indeed by $1170 / 80$ the stronghold at Węgry, along with its associated settlement had been abandoned, as well as the settlement complex to the north at Wielbark (site 2) (Haftka, 1987: 37-41). Nearby, at Wielbark (site 18), excavations in the early 1960s uncovered features containing Pomeranian ceramics broadly dated from the ninth to thirteenth centuries (Jagodziński 1997: 135). The dating resolution of other settlements within the vicinity is equally poor; $10 \mathrm{kms}$ to the north-east at Kaczynos (formerly Katznase), fragments of ceramics have been linked to a Pomeranian settlement dating to the twelfth and thirteenth centuries. At the same time, the 
presence of Prussian groups in this macro-region is suggested by finds of Baltic ceramics in Malbork, which have been broadly dated from the ninth to thirteenth century (Dąbrowska 2007: 305; Jagodziński 1997). The recovery of iron axes (type 3, dated to the thirteenth century) in the moat of the high castle in Malbork, and during building work in nearby Piaski in 1967 cannot be readily linked to the presence of one group or another; Prussians evidently re-used and traded weapons, and were comparably armed to their Slavic neighbours (Kittel 2002).

The main source for the events of the Prussian Crusade is the Chronicon Terrae Prussiae (The Chronicle of the Prussian Lands) of Peter of Dusburg, a priest of the Teutonic Order who completed his narrative by 1326. This text was written for a papal audience as an apologia for the Order's crusades, and drew upon earlier accounts (Trupinda 1999: 65-77). Peter's narrative is ideologically charged and his attention to detail is not always accurate. His description of the pacification of the territory of Pomesania after the battle of Christburg (Dzierzgoń) in the winter of 1233/34 (Peter of Dusburg's Chronicle III: 11; ${ }^{1}$ Powierski 2003: 120) provides no further details. However, the allegiance of the Pomesanians was only secured a decade later with the Treaty of Christburg (1249), following the defeat of the First Prussian Uprising. Within the vicinity of Biała Góra and the Forest of Sztum, the sparse archaeological data may suggest limited or temporary activity in this macro-region by the 1230s. Dusburg's Chronicle (III: 14) refers to Sztum as the location of a Prussian fortification in the first decade of the crusading period - an identification that has yet to be verified archaeologically (Haftka 2010: 145). The location of Sztum is described as one of a number of Prussian propugnacula and castra (varieties of fortification) destroyed by the Margrave of Meissen and his crusading host in 1236. Despite Peter's inconsistent geographic statements, it is evident that the Order considered the territory to the north-east of Kwidzyn, encompassing Sztum and Prabuty, as Prussian by the onset of the crusades. Prussians may have started to settle here from the mid-twelfth century, subsequently expanding southwards and eventually threatening the Kulmerland (Szczepański 2011: 12-13). The archaeological evidence for this is tentative, partly due to the lack of excavated rural settlements - the focus has been on strongholds. Although it is tempting to link the abandonment of the local power centre at Węgry with Prussian incursions, some $7 \mathrm{kms}$ to the south-west and $10 \mathrm{kms}$ directly across the woods from Sztum, there is no evidence for Prussian material culture where the site of Biała Góra 3 flourished in the thirteenth century. The combined evidence suggests that by the start of the crusading period the various individual woods described in written sources - forming the expansive Forest of Sztum - had become the focus of a more sharply divided frontier. This was not an impassable barrier, and the region was attacked on multiple occasions by Prussian armies reaching as far as sites overlooking the Vistula and Nogat, including Zantyr (Peter of Dusburg's Chronicle III: 143, 192).

Following the crusades, a new settlement pattern in the macro-region develops. With the exception of Biała Góra, there is virtually no archaeological continuity between pre- and post-crusade sites (fig. 5; Haftka 1987). However, some of these later thirteenth and fourteenth-century settlements were established on or near sites with evidence for earlier occupation, suggesting that perhaps their locations were known, their geographical situation in relation to routes crossing the Lower Vistula region remained attractive to colonists, and in some cases traces of earlier structures may even have been visible. This was not always the case: the stronghold at Węgry was not re-occupied and the later medieval settlement of Wengern developed a few kilometres from the site. The new theocratic authorities - the

\footnotetext{
${ }^{1}$ All references to Peter of Dusburg's Chronicle are from the edition by Wyszomirski and Wenta 2011.
} 
Teutonic Order and bishops - were responsible for deciding where new settlements would be located, evidently within the framework of a regional strategy for reorganising the resources of the conquered landscapes. In contrast to the earlier phase of colonisation, the new settlement pattern was subordinated to the emerging system of commanderies: units of territorial organisation gradually introduced by the Teutonic Order during and after the crusading period. A hierarchy of settlements quickly emerged and can, in part, be linked to commercial roles. The material expression of this can be found in the organisation of street plans in the earliest phases of Thorn (Toruń) and Elbing (Elbląg), as well as the presence of imported glazed pottery already evident by the mid-thirteenth century (Rębkowski 1997). Commerce and crusading were inextricably linked in the southern Baltic, and the provisioning of trading centres would have required not only reliable trading networks, but also effective connections with urban hinterlands. The settlement at Biała Góra, though to our knowledge, not a market for imported glazed wares per se, was certainly an important link in the trade network that enabled the theocratic Ordensland to develop.

\section{Biała Góra: A colony on the edge of Pomesania}

The site is situated just to the north of the modern village of Biała Góra, on the edge of an escarpment overlooking the eastern edge of the River Nogat's floodplain. Field and gradiometer surveys followed by excavations in 2007 and 2011 indicated the presence of an open settlement covering some four hectares, located on the western edge of the Forest of Sztum which appears to have extended down to the floodplain (fig. 6). The site was perfectly placed at the confluence of the Vistula and Nogat, enabling it to control and take advantage of the communication routes leading up to the Vistula Lagoon and the Bay of Gdańsk, whilst the Forest of Sztum presented a formidable obstacle to colonisation and, indeed, may have been deliberately preserved as a managed resource. Micromorphological analysis of the 'dark earth cultural layer', spread across the site, indicated intensive and relatively short-lived occupation, corresponding to a significant quantity of artefacts and ecofacts recovered from this horizon and over a hundred associated features. The majority of these were pits (fig. 7), with some traces of timber buildings and caches of bricks, roof tiles and stones. The site's chronology was established from a combination of AMS dates, coins and several categories of artefacts, including boat sintels and ceramics. Its initial phase of activity was dated to the late-twelfth/first half of the thirteenth century, associated with the pre-crusade Pomeranian settlement. A second distinct - and more intensive - phase could be dated to the second half of the thirteenth century, characterised by Pomeranian and Teutonic Order material culture appearing in the same contexts. The final phase was dated from the fourteenth through to the early fifteenth centuries, with a noticeable reduction in activity. The artefacts recovered from the site point to a composite community with the presence of small-scale industry, commerce and military personnel (Pluskowski et al. 2014).

The majority of features contained domestic refuse, typically a mixture of animal bone, ceramics and metal artefacts, with the deepest pit cutting $1.5 \mathrm{~m}$ into the natural sandy soils. Two pits (features 25 and 82) contained the largest deposits of animal bone, although there was no evident patterning in waste disposal practices. By far the largest category of artefacts is represented by ceramics. Over ten thousand fragments of pottery have been recovered from the cultural layer and pits at the site, mostly small fragmented pieces. Whilst further analysis is on-going, it is possible to sub-divide them into two categories: the so-called 'traditional' or Pomeranian type, and 'greyware' datable to the thirteenth and fourteenth centuries. Both types were wheel-thrown, with the traditional pottery fragments characterised by a limited range of standardised pots fired in oxidising or uncontrolled conditions, and the fabric 
tempered with a coarse-grained mixture of sand, gravel and grog. The range of greyware vessel forms is much more diverse, consisting of different types of pot, handled pitchers and lids made from a homogenous compact fabric, tempered with fine-grained sand and fired in a reducing atmosphere within a kiln. The presence of both traditional and greyware ceramics in the same contexts within the same pits strongly suggests a period when both types were produced at the same time, with two very different technologies present at the site (Pluskowski et. al 2014). The closest parallels of the type of greyware recovered from Biała Góra have been found in significant quantities in the Old Town of Elbląg, attributed to German colonists from Lübeck, Upper Saxony and Thuringia, via Silesia in the second half of the thirteenth century (Marcinkowski, 2003).

The presence of, or direct contact with, the Teutonic Order is suggested by finds of bracteates (fig. 8). These date to the first three decades of the fourteenth century, produced within the already established theocratic Ordensland. The range of military equipment, including spurs and a heraldic dress accessory, suggests that knights and other rank and file were present at the settlement, dated to the period when the Order had become the political power on the eastern side of the Lower Vistula valley. The role of monastic/military orders in the development of the settlement is also strikingly evident from the presence of brick at the site. In Pomerelia, brick buildings had been introduced by the Cistercians and are evident in Gdańsk from the latter half of the thirteenth century (Paner, 2001: 496). Within the Teutonic Order's colonies, the earliest uses of brick can also be dated from the mid-thirteenth century (Chudziakowa, 1983: 17-19; Nawrolska, 2001: 477; 2004: 303; Chruścińska et al. 2008). It is possible the settlement produced bricks to supply other sites, such as the castle and town at nearby Marienburg. Some castles had their own brickyards, whilst others had to purchase their materials from external suppliers (Gancewski, 2001: 88). Bricks could be easily transported to various sites along the Vistula and Nogat, and the presence of significant brick caches at Biała Góra, clearly abandoned, lends some credence to the idea of an attempted or partially successful relocation of building materials.

After a relatively short period of co-existence, the intensity of activity in the settlement visibly decreases, although there is evidence for the use of the site into the first half of the fourteenth century, after which there are only sporadic examples of fifteenth century material culture, such as boat sintels. The absence, to date, of any imported ceramics also confirms the site's disconnection from the later Hanseatic trade networks which used the Vistula and Nogat extensively in the fourteenth and fifteenth centuries. Moreover, the landscape around Biała Góra became a temporary military frontier again in the fifteenth century; the subject of incursions in 1410 and also during the Thirteen Years War (1454-66), which clearly had a detrimental effect on the towns and settlements in the region. Yet the instability of the documented events of the crusading period and the fifteenth century is contrasted with the sustained development of the landscape associated with protracted waves of colonisation. The successful maintenance of the borderland colonies necessitated reliable sources of provisioning, as well as access to fuel and building materials - clearly attested in the palaeoenvironmental data associated with Biała Góra and its vicinity.

\section{Sustaining colonisation through environmental exploitation}

Irrespective of the geo-political situation in the northern Pomeranian-Prussian borderlands in the twelfth and early thirteenth centuries, the expansive wetlands of the Lower Vistula floodplain, delta and fenlands prevented the establishment of a dense settlement network before the crusades. Settlement was clustered along the escarpments either side of the Vistula 
and Nogat, and in the case of the latter around the fringes of a significant expanse of woodland. The colonies had to be supported with an effective system of provisioning, either imported from a distance or obtained from the local hinterland. Gdańsk itself developed an intensively managed hinterland to sustain its growing population, with pollen evidence suggesting large-scale deforestation and an increase in cereal cultivation from the tenth/eleventh century (Latałowa et al. 2009). Pollen and macrobotanical data from urban excavations within Gdańsk suggest the immediate environs were almost totally deforested by the beginning of the twelfth century (Święta-Musznicka et al. 2013). Remains of useful plants are increasingly prevalent in deposits dating to the thirteenth century and later, including significant quantities of charred cereals, typically stored in granaries for export, and rarer imported exotic spices (Badura 2011). These remains attest to the growing economic importance of the city during the late medieval period following its annexation by the Teutonic Order in 1309, and subsequent membership of the Hanseatic League from 1358. The most abundant data for provisioning from a smaller colony is derived from Biała Góra.

\section{Woodlands and fields}

A detailed programme of coring for palynological analysis focused on the landscape within the commandery of Marienburg, particularly to the south of the castle around Biała Góra and the Forest of Sztum (fig. 9). The aim of the coring was to target suitable deposits representative of the likely range of landscape settings and patterns of land-use occurring within the area, both in proximity to castles, urban and rural sites, areas more remote from settlement, and deposits encircling the current edges of the Forest of Sztum. Not all cores produced material suitable for analysis. Pollen was poorly preserved or entirely absent from the sequences at Sztum and Pietrzwałd, whilst the sequences at Kalwa, Weqgry and Sztumskie Pole had been truncated with sediments of medieval and later date removed altogether. However, suitable sequences were produced from Parpary, Benowo, Gościszewo and Stary Targ, with analysis currently underway from Koniecwałd.

These pollen studies provide a picture of changing landuse and environment within the wider landscape around Biała Góra over the course of the medieval period, with evidence both for significant deforestation and agricultural expansion, and in other places, maintenance of preexisting tracts of woodland. The sequence from Gościszewo has been previously discussed along with pollen from the inner moat at Malbork Castle (Brown and Pluskowski 2011). In common with the sequences from Parpary, Benowo and Stary Targ, they demonstrate that the landscape during the Migration Period was dominated by woodland composed largely of hornbeam and oak with limited evidence for human activity. Typically only very occasional cereal pollen grains were recorded, along with both small quantities and a low diversity of herbaceous plants charactersitic of either arable, pastoral or disturbed habitats, suggesting a rather sparse settlement pattern with only minimal impact on the landscape.

However, woodland begins to decline in pollen sequences broadly from the eighth/ninth century, accompanied by an increase, albeit marginal, in cereals and anthropogenic indicators, evident to varying degrees in these profiles (fig. 10), and equally in profiles from adjoining regions (e.g. Hjelmroos 1981; Noryśkiewicz 2005; Lamentowicz et al 2008; Latałowa et al 2009). The first Pomeranian strongholds appear at this time, but seem to have had a fairly limited impact on a still largely woodland landscape, reflecting the rather precarious nature of the settlement pattern. Continued woodland clearance and increasing cereal pollen values are apparent from both the Gościszewo and Stary Targ sequences through the tenth-twelfth centuries, most probably reflecting continued Pomeranian 
settlement. There is comparatively limited human activity apparent in the Benowo and Parpary sequences at this time, but this may largely reflect their location within the boundaries of the Forest of Sztum.

The most significant changes are apparent from the thirteenth century onwards. Substantial woodland clearance and cereal cultivation are apparent in the Parpary sequence and clearly relate to the nearby colonising settlement. Today, Parpary is a small, dispersed settlement located within the edges of the Forest of Sztum that during the medieval period most probably functioned to exploit the resources of the woodland. Cereal pollen includes the more widely produced and dispersed wind-pollinated rye, as well as self-pollinated and thus poorly produced and dispersed, wheat/oat and barley. Taken together, the cereal pollen may largely reflect the agricultural activities of Parpary, but does not exclude the possibility that a proportion of the cereal pollen, particularly rye, derives from arable fields beyond the margins of the woodland. Moreover, the pollen reflects cultivation of both winter and summer crops, that along with pollen of segetal flora (i.e. those accompanying crops) such as cornflower, is strongly suggestive of the development of permanent rotational field systems (Vuorela 1986). A similar picture is apparent at Stary Targ, likewise associated with a nearby colonising settlement, and from Gościszewo, in both cases within a landscape more widely cleared of trees and today predominantly agricultural in comparison to Parpary. Benowo, however, demonstrates a pattern of woodland continuity throughout the medieval period, being located within the current central part of the Forest of the Sztum. The structure of the woodland canopy changes from the tenth century, with hornbeam declining, a characteristic feature of pollen diagrams across the lower Vistula basin (see Ralska-Jasiewiczowa et al. 2004), progressively replaced by increasing values for pine. Pine is well adapted to colonising disturbed habitats (Latałowa et al. 2004), but has widely dispersed seeds and pollen, and therefore very likely reflects broader trends in vegetation and landuse within the wider landscape beyond the Forest of Sztum. Woodland continuity is also evident in the pollen sequence from Koniecwałd (formerly Conradswalde - "Conrad's wood") where pine predominates with only very occasional pollen grains of rye recorded; suggesting the edge of the woodland may have projected a little further north than the present-day.

The results of pollen analysis summarised here serve to demonstrate the significant changes in landscape and landuse occurring during the late medieval period. Agricultural landuse became increasingly intensive from the thirteenth century, continuing a pattern begun in the eighth/ninth century and reflecting the progressive colonisation of the landscape by successive Pomeranian and German groups. Intensive landuse can be viewed in the context of the requirement to provision both rural and urban settlements, such as Biała Góra, and the heavily fortified castles, but also surplus grain production supplying the well-documented export trade in grain to Western Europe and Scandinavia (Hybel 2002). However, it is strikingly clear that substantial tracts of existing woodland, such as the Forest of Sztum, were actively maintained throughout the medieval period, and documented as actively managed landscapes in the fourteenth and fifteenth centuries (Chęć and Gancewski 2009).

These changes in landuse are also evident in the plant materials recovered from excavated features at Biała Góra, with the majority consisting of charred remains (fig. 11). Samples from eight features contained substantial quantities of plant diaspores which can be linked to specific agrarian activities at the site. The most abundant are traces of cereals, including grains of rye and barley. Single grains of wheat and millet were also found in two pits, although it seems that these two species did not play an important role at the site. There were also no residues of rachis or glumes. Apart from crops, charred seeds of pea were noted in 
one feature, and wild useful plants were represented by two charred hazelnut shell fragments and one mineralised seed of a raspberry. A valuable feature of the assemblage is the relatively high proportion of weeds. The majority represent segetal flora and include common corncockle, black-bindweek, false cleavers and cleavers/corn cleavers. Plants that could belong to both segetal and ruderal flora are represented by single diaspores of curlytop knotweek, common chickweeds and a significant number of fruits from the Chenopodium species.

The results of the macrofossil analysis contribute particularly to our understanding of the types of agrarian resources that were accessible to the community at Biała Góra. The range of cereals and weeds indicates the presence of permanent rotational field systems or perhaps to imported grain, although the intensity of crop production is difficult to gauge. Finds of sickles and quernstones certainly point to local harvesting and cereal processing on site. The fruits and nuts present at the site could also have been sourced locally, from the fringes of the nearby woodland. Further results will be complemented by charcoal and wood analysis, and integrated with the full range of palaeoenviromental data. However, the crusading period does not coincide with a significant hiatus in local agriculture.

\section{Livestock}

Alongside fields, extensive pasture would have been required to support any livestock reared in the borderland colonies. At Biała Góra, these would have ranged from meadows in the floodplain through to the woodland beyond the settlement. The majority of the 2841 bone fragments recovered from the site in 2008 largely derive from the remains of domestic mammals (c. $92 \%$ of the assemblage). ${ }^{2}$ The most frequently represented species was pig, closely followed by cattle and a significantly smaller number of sheep and goat bones, comparable to the representation of horse. The community here was clearly reliant on pigs and cattle for its meat and related products such as leather, particularly derived from animals that were raised, slaughtered and butchered on site (Pluskowski et. al 2014). The high proportion of pig remains is typical for sites in this region (Makowiecki, 2009: 430), and one that can be linked to the Forest of Sztum, providing readily accessible, seasonal pannage and woodland pasture. With the establishment of the Ordensland, the exploitation of the woodland would be managed by specialised manors or Vorwerks (Polish folwarki) situated around the edges and subservient to the convent at Marienburg (Chęć 2003, 2009). Cattle, sheep, goats and horses could be supported with varying types of grazing, with the likelihood of nearby meadows also suggested by the presence of rooks in the assemblage (Kasprzykowski 2003: 29). The organic waste generated by the colony would have supported a range of smaller commensals, including cats. Cats are infrequently found in this region before the thirteenth century, when increased urbanisation coincides with increased numbers of this commensal (Makowiecki 2009: 435).

The biological profiles of neighbouring frontier sites, particularly Węgry and the multi-period sites at Gniew provide a local context for Biała Góra. The quantity of recovered animal bone from the former was comparable in size, dominated by cattle and pig with wild species restricted to a few fragments of red and roe deer, wild boar and hare (Sobociński 1981). Węgry's biological profile is typical of the higher status stronghold sites associated with early medieval colonisation in the Lower Vistula (Makowiecki 2009). The larger assemblages from

\footnotetext{
${ }^{2}$ Excludes over 2000 fragments of unidentifible mammal bone flakes recovered through careful collection and sieving.
} 
various locations in Gniew, representing at least six occupation phases, indicate the prevalent role of cattle in the medieval urban meat supply, diversity in pig and horse breeding, as well as access to more open and wooded landscapes (Sobociński and Makowiecki 1992). This is typical of later medieval town sites, and whilst Biała Góra's biological profile is comparable to that of early medieval Pomeranian strongholds, it is differentiated by a higher level of biodiversity associated with a more pronounced exploitation of the full spectrum of local habitats (see below). This range of exploitation is more readily associated with larger centres such as Gdańsk or Kałdus (Makowiecki, 2009). It supports the notion that colonies such as Biała Góra developed an extensive hinterland to support their provisioning requirements encompassing a mosaic landscape.

\section{Hunting and trapping for meat and fur}

Wild mammals make up a small percentage of faunal assemblages in all the borderland sites; at Gniew there is evidence for the occasional hunting of roe deer, hare, wild boar and beaver (Sobociński and Makowiecki 1992). Whether their meat was acquired as part of the community's 'buffer economy', or whether it can be linked to a more exclusive hunting culture is difficult to determine; there is not enough data to enable mortality profiles to be reconstructed for these species. At Biała Góra the presence of red deer, roe deer, hare and potentially wild boar point to occasional encounters in the varied landscapes within the site's hinterland. Encounters with wild carnivores must have been even more infrequent, as represented by fragments of bear, fox and a possible wolf, whilst the presence of otter, polecat, and marten (most likely Pine Marten), derived from species whose pelts had established commercial value (Delort 1978). The majority of wild mammal species represented at Biała Góra prefer woodland habitats, with hare and roe deer reflecting the presence of more open landscapes at the fringes of the Forest of Sztum. The virtual absence of wild birds at the site is striking and clearly not a product of archaeological recovery techniques, moreover the local wetlands were intensively exploited as suggested by the quantity and diversity of fish remains.

\section{Fishing}

The hydrological network of the Lower Vistula borderlands facilitated extensive access to freshwater fish. Whilst fish remains have been reported at a number of early and later medieval sites in this region, particularly settlements associated with strongholds such as Charzykowy, Chmielno (site 1) and Ciepłe (site 3), there is to date very little published, quantifiable data. This has made it difficult to contextualise the development of fishing during this protracted period of colonisation. The exception is the settlement at Gniew (site 2), already mentioned above. On the basis of these assemblages it is clear that at least 18 species of fish were found in the waters of this region during the Middle Ages, with exploitation of marine species evident at sites associated with the emerging Polish state (e.g. herring from Kałdus) and the Teutonic Order's state (e.g. cod from the castle at Mała Nieszawka (Nessau)). At Biała Góra, 20 different species were represented within the assemblage of 989 fish bones (fig. 12). A large quantity of fish scales $(n=1246)$ were also recovered from the site, primarily deriving from cyprinids. A broad diversity of aquatic habitats were represented by the fish remains; freshwater, migratory and marine species, including sturgeon and cod, the latter relatively small in size $(30-60 \mathrm{cms})$ and derived from the population in local Baltic waters. This can be linked to the emergence of a local fishing industry following the crusades; isotopic studies have suggested that cod - even in Gdańsk were previously sourced from Scandinavian waters (Orton et al. 2011). The presence of cod 
is first evident in Gdańsk from the end of the thirteenth century/early fourteenth century whilst carp, present in the town from the thirteenth century, is documented at Marienburg castle in 1396 and subsequently in the fifteenth century (Chęć 2009; Makowiecki 2003: 116).

The vast floodplains of the Vistula and its tributaries were progressively embanked and drained for agriculture and settlement from the fourteenth century, but particularly between the sixteenth and nineteenth centuries, with the rivers canalised and their courses stabilised (Kowalik 2008). However, during the medieval period this would have been a dynamic environment of semi-terrestrial marshland, periodically flooded and flanked in places by inland river dunes of sub-aqueous origin. Windblown sands from these dunes occur extensively across the site, both under and overlying the cultural horizon. The Nogat, originally a separate river, had most likely merged with the Vistula at Biała Góra by the thirteenth century. The first half of the fourteenth century is characterised by extensive hydrological modifications within Marienburg's commandery, which included attempts at controlling flooding and land reclamation. The colonisation of the Vistula fenlands driven by the Teutonic Order prompted the embanking of the Nogat, severing a number of its lateral distributaries, altering its course and increasing its sediment load, which in turn had a detrimental effect on the river's navigability in its northernmost stretch (Długokęcki 1993: 39). Moreover, the extraction of clay for the manufacture of vast quantities of brick could have equally impacted on local hydrology, but is difficult to quantify or even provenance without detailed geochemical study. The assemblage of fish bones from Biała Góra, as well as finds of hooks of varying sizes and fishing weights, indicates that intensive and diverse fishing was practiced at the site during the period of colonisation and modification of the Vistula's floodplains. The presence of beavers at the site (represented by 40 bone fragments derived from at least four individual animals, with cut marks indicative of meat removal), provides further evidence of both the dynamic nature of these wetlands and their holistic exploitation by the colony.

In summary, the suite of environmental evidence recovered from Biała Góra provides us with a more detailed understanding of the relationship between a colony and its hinterland in the Vistula borderlands. Whilst this period is associated with turbulent historical events, the archaeological and palaeoenvironmental evidence suggests a level of stability required to develop the provisioning networks which sustained this settlement.

\section{Conclusion: from colonising frontier to theocratic heartland}

The place name of the modern village of Biała Góra - named Weißenberg before 1945 - is first mentioned in the sixteenth century. Its chronology and relationship with the adjacent medieval colony remain to be verified archaeologically. This colony, initially established within the broader context of the expansion of the north-western duchy of the Polish Christian state, appears to have been the only one that endured throughout the thirteenth century. The colony was subsequently re-founded or further developed by a new wave of settlers who introduced a different type of firing technology, represented by significant quantities of greyware ceramics. The proximity of the river and the woods provided the site with natural shelter within a region that remained a complex and dynamic military frontier between Pomeranian Slavs, Prussians and the Teutonic Order until the second decade of the fourteenth century. At the same time, the colonists exploited a diverse range of habitats within its hinterland, the boundaries of which are difficult to ascertain, but certainly included areas of the river, floodplain, escarpment and woodland, most probably managed in parts. The decline in activities at the site can be linked to the transformation of this frontier zone 
into a political heartland within the Teutonic Order's theocratic state. In 1309 the headquarters of the Order were relocated to Marienburg, accelerating the reconfiguration of the management of the surrounding landscape; a process that had already begun in the 1280s with the designation of the early castle as a convent (Powierski 1979; Jóźwiak and Trupinda 2007).

The site at Biała Góra may correspond to the historically documented Santir or its periphery: a Pomeranian, Cistercian missionary outpost functioning in the early-thirteenth century and subsequently a Teutonic Order commandery centre (rendered variants include Zantyr, Zantir, Cantiro, Czantyr, Czanterz etc; Górnowicz 1990: 141-142). This was officially relocated to Marienburg by 1280 , four years after both convents are mentioned as the responsibility of the same commander (for a discussion of the problematic date of relocation see Pollakówna 1967: 416-417; Powierski 1979; Jóźwiak and Trupinda 2007:53). The association between Zantyr and Biała Góra, as well as its relocation, was maintained by local inhabitants into the eighteenth century, and remains the most likely location for the early commandery centre (Pollakówna 1967; Haftka 1971; Powierski 2003: 115). The fragmentary written sources for the period indicate that Zantyr was considered to be strategically important in shaping the political frontier in the Lower Vistula valley during the thirteenth century. Its acquisition by the Order and tensions over the control of the Vistula led to a war with Duke Świętopełk of Gdańsk from 1242-1253, during which the stronghold was briefly recovered. It was subsequently returned to the Prussian archbishops and ceded to the Order by 1251 . The latter half of the thirteenth century saw the consolidation of Zantyr's (and later Marienburg's) commandery, as well as the Order's acquisition of land on the western side of the Vistula in 1282 (Powierski 2003: 80). At this point its documented role diminishes; Zantyr continues to occasionally feature in records until the fifteenth century, particularly its fortification in 1465 . Whilst it appears on a map from 1576 (fig. 13), its former location adjacent to Weißenberg is mentioned in 1665 (Pollakówna 1967: 418).

Extensive field walking and coring by the Archaeology Department from the Castle Museum in Malbork within the vicinity of the site (including the western stretches of the Forest of Sztum) has not yielded comparable evidence of intensive settlement between this site and the early medieval centre at Węgry, which was abandoned before the site at Biała Góra was established. Overall, this reinforces the notion of a more complex process of colonisation within the Lower Vistula borderlands. Much of what is known about the foundation of settlements between the end of the Viking Age and the Prussian Crusade is derived from surface finds, rather than excavated settlements. In this respect the uniqueness of Biała Góra needs further clarification. This could be achieved by adopting the intensive test pit excavation strategy (Lewis 2007), focused on areas already identified by the AZP and Adalbertus programmes, as well as within existing settlements which may have origins in the later medieval period. Alongside future excavations at Biała Góra, this will contribute significantly to our understanding of how the waves of multi-ethnic colonisation across the Vistula fenlands were sustained and superseded, facilitating the transformation of this frontier into a political and economic heartland.

\section{Acknowledgements}

The excavations at Biała Góra were undertaken and supported by the Castle Museum in Malbork (Muzeum Zamkowe w Malborku), and the authors would like to thank all those who participated, in particular Waldemar Jaszczyński. The gradiometer survey was conducted by David Thornley (University of Reading), using a Bartington Grad 601-2 dual fluxgate 
gradiometer. Animal bone was identified according to the reference collections in the Grahame Clarke Laboratory at the University of Cambridge, the Department of Archaeology at the University of Reading and the Natural History Museum in London. Fish bone was identified according to the collections at the Institute of Archaeology, of the University of Nicolaus Copernicus in Torun. Plant macrofossils were identified using modern reference material from the collection housed at the Laboratory of Palaeoecology and Archaeobotany at the University of Gdańsk. Thin section micromorphology slides were prepared by John Jack (University of Reading). The authors would like to extend their thanks to Seweryn Szczepański for his advice and suggestions in the preparation of this article. The research leading to these results has received funding from the European Union's Seventh Framework Programme (FP7/2007-2013) under grant agreement $n^{\circ} 263735$. Part of the archaeobotanical work has been carried out within the parallel project 2012/05/B/ST10/00243, financed by the National Science Centre in Poland.

\section{References}

Auch, M. Bogucki, M. Trzeciecki, M. 2012. Osadnictwo wczesnośredniowieczne na stanowisku Janów Pomorski 1. In M. Bogucki and B. Jurkiewkicz, eds. Janów Pomorski Stan. 1. Wyniki ratowniczych badań archeologiczynch w latach 2007-2008. Elbląg: Muzeum Archeologiczno-Historyczne w Elblągu, pp.23-232.

Badura M. 2011. Rośliny użytkowe w dawnym Gdańsku. Studium archeobotaniczne. Gdańsk: Wydawnictwo UG.

Biskup, M., Czaja, R., Długokęcki, W., Dygo, M., Jóźwiak, S., Radzimiński, A. and Tandecki, J. 2009. Państwo zakonu krzyżackiego w Prusach. Władza i społeczeństwo. Warszawa: Wydawnictwo Naukowe PWN.

Brown, A.D. and Pluskowski, A.G. 2011. Detecting the environmental impact of the Baltic crusades on a late medieval (13th-15th century) frontier landscape: Palynological analysis from Malbork castle and hinterland, northern Poland. Journal of Archaeological Science, 38: 1957-1966.

Buko, A. 2008. The Archaeology of Early Medieval Poland. Leiden: Brill.

Chęć, A. 2003. Folwarki krzyżackie na terenie komturstwa malborskiego w świetle źródeł archeologicznych i historycznych, próba lokalizacji. In K. Grążawski, ed. Pogranicze polskopruskie i krzyżackie. Włocławek: Lega, pp. 325-338.

Chęć, A. 2009. Hunstsmanship and hunting weapons in Malbork commandery. In J. Maik, ed. Fasciculi Archaeologiae Historicae: The Hunt and Hunting Weapons in Antiquity and the Middle Ages. Łódź: Polish Academy of Sciences, pp. 95-100.

Chęć, A. and Gancewski, J., 2009. Urząd leśniczego w państwie zakonu krzyżackiego funkcjonowanie, znaczenie dla gospodarki. In W. Łysiak, ed. Las w kulturze polskiej, $t$. VI, Poznań: Eco, pp. 47-56.

Chruścińska, A. Jesionowski, B. Oczkowski, H. L. and Przegiętka, K. R. 2008. Using the TL single-aliquot regenerative-dose protocol for the verification of the chronology of the Teutonic Order castle in Malbork. Geochronometria 30: 61-67. 
Chudziak, W. 1994. Podstawy klasyfikacji chronologicznej grodzisk. In J. Chudziakowa, ed. Wczesnośredniowieczne grodziska ziemi chetmińskiej. Toruń: Wydawnictwo UMK, pp. 2428.

Chudziak, W. 2003. Wczesnośredniowieczna przestrzeń sakralna in Culmine na Pomorzu Nadwiślańskim. Toruń: Wydawnictwo UMK.

Chudziak, W. 2006. Stan i potrzeby badań nad wczesnym średniowieczem Pomorza Nadwiślańskiego. In W. Chudziak and S. Moździoch, eds. Stan i potrzeby badań nad wczesnym średniowieczem w Polsce - 15 lat później. Toruń: Wydawnictwo UMK, pp. 175187.

Chudziakowa, J. 1983. Toruń najdawniejszy i wczesnośredniowieczny. In M. Biskup, ed. Toruń dawny i dzisiejszy: Zarys dziejów. Warszawa: Wydawnictwo Naukowe PWN, pp. 1130 .

Dąbrowska, M. 2007. Badania archeologiczno-architektoniczne na terenie zamku niskiego w Malborku w latach 1998-2004. In G. Nawrolska, ed. XV Sesja Pomorzoznawcza. Elbląg: Muzeum Archeologizno-Historyczne w Elblągu, pp. 303-316.

Delort, R. 1978. Le Commerce des fourrures en Occident à la fin du Moyen Age (vers 1300vers 1450), 2 volumes. Rome: École Française de Rome.

Długokęcki, W. 1992. Osadnictwo na Żuławach w XIII i początkach XIV w. Malbork: Muzeum Zamkowe w Malborku.

Długokęcki, W. 1993. Zmiany koryta Wisły i Nogatu pod Białą Górą od XIII do pierwszej połowy XVI wieku. Przyczynek do historii żeglugi wiślanej. Rocznik Gdański, 53 (2): 27-39.

Długokęcki, W., Kuczyński, J. and Pospieszna, B. 2004. Młyny w Malborklu i okolicy od XIII do XIX wieku. Malbork: Muzeum Zamkowe w Malborku.

Fonnesberg-Schmidt, I. 2007. The Popes and the Baltic Crusades 1147-1254. Leiden: Brill.

Gancewski, J. 2001. Rola zamków krzyżackich w ziemi chetmińskiej od połowy XIV wieku do 1454 roku. Olsztyn: Ośrodek Badań Naukowych im. Wojciecha Kętrzyńskiego.

Gładysz, M. 2012. The Forgotten Crusaders: Poland and the Crusader Movement in the Twelfth and Thirteenth Centuries. Leiden: Brill.

Górnowicz, H. 1980. Toponimia Powiśla Gdańskiego. Wrocław: Zakład Narodowy im. Ossolińskich.

Haftka M. 1971. Uwagi w sprawie wczesnośredniowiecznego osadnictwa w północnej Pomezanii i kwestia lokalizacji Santyra. Pomorania Antiqua 4: 455-476.

Haftka, M. 1987. Mikoreregion osadniczy Węgry-Gościszewo-Malbork w świetle kilkunastoletnich obserwacji terenowych. In A. Pawłowski, ed. Badanaia archeologiczne w woj, elblaskim w latach 1980-83. Malbork: Muzeum Zamkowe w Malborku, pp. 27-42. 
Haftka, M. 2010. Zamki krzyżackie: Dzierzgoń - Przezmark - Sztum. Malbork: Muzeum Zamkowe w Malborku.

Hjelmroos, M. 1981. The post-glacial development of Lake Wielkie Gacno, NW Poland. The human impact on the natural vegetation recorded by means of pollen analysis and 14C dating. Acta Palaeobotanica, 21: 129-144.

Hybel, N. 2002. The grain trade in northern Europe before 1350. Economic History Review, 45: 219-247.

Jagodziński, M. F. 1997. Archeologiczne ślady osadnictwa między Wisła a Pastęka we wczesnym średniowieczu. Katalog stanowisk. Warszawa: Instytut Archeologii i Etnologii PAN.

Jagodziński, M. F. 2004. Podstawy źródłowe - analiza. Przekazy pisane - odkrycia archeologiczne. In J. Trupinda, ed. Pacifica Terra: Prusowie-Stowianie-Wikingowie u ujścia Wisty. Malbork: Muzeum Zamkowe w Malborku, pp. 21-40.

Jagodziński, M. F. 2010. Truso: Między Weonodlandem a Witlandem. Elbląg: Muzeum Archeologiczno-Historyczne w Elblągu.

Janowski, A. 2007. Wczesnośredniowieczne okucia pochew mieczy tzw. trzewiki z terenu Pomorza, Warmii i Mazur. In M. Bogacki, M. Granz and Z. Pilarczyk, eds. Wojskowość ludów morza bałtyckiego. Toruń: Wydawictwo A. Marszałek, pp. 150-177.

Jóźwiak, S. and Trupinda, J. 2007. Organizacja życia na zamku krzyżackim w Malborku w czasach wielkich mistrzów (1309-1457). Malbork: Muzeum Zamkowe w Malborku.

Kasprzykowski, Z. 2003. Habitat preferences of foraging rooks Corvus frugilegus during the breeding period in the agricultural landscape of eastern Poland. Acta Ornithologica 38 (1): $27-31$.

Kawiński, P. 2011. Organizacja pogańskiej przestrzeni sakralnej Prusów na tle osadnictwa w okresie plemiennym - przykład Pomezanii, Pogezanii i Warmii. Pruthenia 6: 89-128.

Kittel, P. 2002. Średniowieczne uzbrojenie zaczepne Prusów z obszaru północnowschodniej Polski. Komunikaty Mazursko-Warmińskie, 2 (236): 155-187.

Kowalik, P. 2008. Flood control in the Vistula River Delta (Poland). Environmental Biotechnology, 4 (1): 1-6.

Lamentowicz, M., Obremska, M. \& Mitchell, E.A.D. 2008. Autogenic Succession, Land-use Change, and Climate Influences on the Holocene Development of a Kettle-hole Mire in Northern Poland. Review of Palaeobotany and Palynology, 151: 21-40.

Latałowa, M., Badura, M., Jarosińska, J. \& Święta-Musznicka, J. 2007. Useful plants in medieval and post-medieval archaeobotanical material from the Hanseatic towns of northern Poland (Kołobrzeg, Gdańsk and Elbląg). In S. Karg, ed. Medieval Food Traditions in Northern Europe. Copenhagen: National Museum, pp. 39-72. 
Latałowa, M., Tobolski, K. and Nalepka, D. 2004. Pinus L. Subgenus Pinus. In M. RalskaJasiewiczowa, M. Latałowa, K. Wasylikowa, K. Tobolski, E. Madeyska, H.E. Wright. and C. Turner, eds. Late Glacial and Holocene History of Vegetation in Poland Based on Isopollen Maps. Kraków: Polish Academy of Sciences, pp. 169-177.

Latałowa, M., Święta-Musznicka, J. and Pędziszewska, A., 2009. Żródła paleobotaniczne do rekonstrukcji wczesnych etapów rozwoju Gdańska. In: L. Domańska, P. Kittel, and J. Forysik, eds. Środowisko-Człowiek-Cywilizacja (Volume 2). Poznań: Bogucki Wydawnictwo Naukowe, pp. 175-185.

Lewis, K. 2007. New Avenues for the investigation of currently occupied medieval rural settlements: Prelimenary observations from the Higher Education Field Academy. Medieval Archaeology, 51: 133-136.

Makowiecka, M., Paner, H. and Makowiecki, D. 1998. Źródła archeozoologiczne do studiów nad użytkowaniem zwierząt i konsumpcją mięsa w średniowiecznym i nowożytnym Gdańsku. Acta Archeologica Pomoranica, 1: 317-331.

Makowiecki, D. 2003. Historia ryb i rybołówstwa w holocenie na Niżu Polskim w świetle badań archeoichtiologicznych. Poznań: Instytut Archeologii i Etnologii PAN.

Makowiecki, D. 2009. Animals in the landscape of the medieval countryside and urban agglomerations of the Baltic Sea countries. Città e campagana nei secoli altomedievali, Spoleto, pp. 427-444.

Marcinkowski, M. 2003. Średniowieczny warsztat garncarski ze Starego Miasta w Elblągu. Pomorania Antiqua, 19: 193-250.

Nawrolska, G. 2001. Domestic architecture in Elbląg. In R. Dunckel, M. Gläser, U. Oltmanns and J. Scheschkewitz, eds. Lübecker Kolloquium zur Stadtarchäologie im Hanseraum III: der Hausbau. Lübeck: Schmidt-Römhil, pp. 473-489.

Nawrolska, G. 2004. Remarks on infrastructure of the Old Town of Elbląg. In R. Dunckel, M. Gläser, U. Oltmanns and J. Scheschkewitz, eds. Lübecker Kolloquium zur Stadtarchäologie im Hanseraum IV: die Infrastruktur. Lübeck: Schmidt-Römhil, pp. 303-322.

Noryśkiewicz, A. 2005. Preliminary results of study on vegetation history in the Linje Mire region using pollen analysis. Monographiae Botanicae, 94: 118-133.

Okulicz-Kozaryn, Ł. 1997. Dzieje Prusów. Wrocław: Fundacja na Rzecz Nauki Polskiej.

Orton DC, Makowiecki D, de Roo T, Johnstone C, Harland J, et al. 2011. Stable isotope evidence for late medieval (14th-15th c) Origins of the eastern Baltic cod (Gadus morhua) Fishery. PLoS ONE 6 (11): e27568. doi:10.1371/journal.pone.0027568

Paner, H. 1997. The archaeology of Danzig (Gdańsk). In D. Mührenberg, ed. Lübecker Kolloquium zur Stadtarchäologie im Hanseraum I: Stand, Aufgaben und Perspektiven. Lübeck: Verlag Schmidt-Römhild, pp. 277-289. 
Paner, H. 1998-1999. Z badań archeologicznych Gdańska. In E. Choińska-Bochdan, ed. Zotchłani wieków Pomorza Gdańskiego: zeszyt okazjonalny dla upamiętnienia Tysiaclecia Gdańska: 997 urbs Gyddanyzc - 1997 Gdańsk. Gdańsk: Stowarzyszenie Naukowe Archeologów Polskich, pp. 95-119.

Paner, H. 2001. $10^{\text {th }}$ - to $17^{\text {th }}$-century domestic architecture in Gdańsk. In R. Dunckel, M. Gläser, U. Oltmanns and J. Scheschkewitz, eds. Lübecker Kolloquium zur Stadtarchäologie im Hanseraum III: der Hausbau. Lübeck: Schmidt-Römhil, pp. 491-509.

Pawłowski, A. J. 2003. Zamek w Dzierzgoniu w świetle badań archeologicznoarchitektonicznych w latach 1998-2001. In H. Paner and M. Fudziński, eds. XIII Sesja Pomorzoznawcza. Gdańsk: Muzeum Archeologiczne w Gdańsku, pp. 403-430.

Piskorski, J. M. (ed.) 2002. Histographical Approaches to Medieval Colonization of East Central Europe. Boulder: East European Monographs.

Pluskowski, A. G. Sawicki, Z. Shillito, L-M, Badura, M. Makowiecki, D. Zabilska-Kunek, M. Seetah, K. Brown, A. 2014. Biała Góra: The forgotten colony in the medieval Pomeranian-Prussian borderlands. Antiquity, (in press).

Poliński, D. 2003. Późnośredniowieczne osadnictwo wiejskie w ziemi chetmińskiej. Toruń: Wydawnictwo UMK.

Pollakówna, M. 1967. Zantyr. Komunikaty Mazursko-Warmińskie, 4: 473-484.

Powierski J. 1979. Chronologia początków Malborka. Zapiski Historyczne, 44 (2): 5-31.

Powierski, J. 2001. Prusowie, Mazowsze i sprowadzenie Krzyżaków do Polski: Volumes I, II/1, II/2. Malbork: Muzeum Zamkowe w Malborku.

Powierski, J. 2003. Prussica (I). Malbork: Muzeum Zamkowe w Malborku.

Rajman, J. 2009. Grody kasztelańskie a średniowieczne miasta (z genezy pomorskich miast). Stupskie Prace Geograficzne, 6: 5-18.

Ralska-Jasiewiczowa, M., Miotk-Szpiganowicz, G., Zachowicz, J., Latałowa, M. and Nalepka, D., 2004. Carpinus betulus L. - Hornbeam. In M. Ralska-Jasiewiczowa, M. Latałowa, K. Wasylikowa, K. Tobolski, E. Madeyska, H.E. Wright. and C. Turner, eds. Late Glacial and Holocene History of Vegetation in Poland Based on Isopollen Maps. Kraków: Szafer Institute of Botany, Polish Academy of Sciences, pp. 69-78.

Rębkowski M. 1997. Medieval glazed pottery imported into Pomerania. A survey of the present state of studies. In A. Buko and W. Pela, eds. Imported and Locally Produced Pottery: Methods of Identification and Analysis. Warsaw: SSPA, pp. 97-109.

Śliwiński, B. 2004. The Christianisation of Prussia: The Polish contribution until the introduction of the Teutonic Order. In J. Gąssowski, ed. Christianization of the Baltic Region, Pułtusk-Frombork: WSH; Bałtycki Ośrodek Badawczy, pp. 39-63. 
Sobociński, M. 1981. Pożywienie mięsne mieszkańców osady otwartej kultury łużyckiej i wczesnośredniowiecznej oraz grodu wczesnośredniowiecznego w miejscowości Węgry, woj. gdańskie. Roczniki Akademii Rolniczej w Poznaniu 131: 95-103.

Sobociński, M. and Makowiecki, D. 1992. Zwierzęce szczątki kostne z wykopalisk w Gniewie nad Wisłą. Stanowisko 2. Roczniki Akademii Rolniczej w Poznaniu, 237: 161-195.

Święta-Musznicka, J., Latałowa, M., Badura, M. and Gołembnik, A. 2013. Combined pollen and macrofossil data as a source of reconstructing mosaic patterns of the early medieval urban habitats - a case study from Gdańsk, N. Poland. Journal of Archaeological Science, 40: 637-638.

Szczepański, S. 2010. Review of Joachim Stephan, Osadnictwo pruskie $i$ kolonizacja krzyżacka w komturstwie Dzierzgoń. Pruthenia 5: 285-292.

Szczepański, S. 2011. Osadnictwo pruskie w okolicy Prabut we wczesnym średniowieczu. Kronikarskim Piórem, 1: 5-15.

Szczepański, S. 2013. Chomor Sancti Adalberti (1249) a możliwości lokalizacji terenowej wybranych kościołów Pomezanii. Komunikaty Mazursko-Warmińskie 1 (279): 19-45.

Trupinda, J. 1999. Ideologia krucjatowa w kronice Piotra z Dusburga. Gdańsk: Officina Ferberiana.

Trupinda, J. (ed.) 2004. Pacifica Terra: Prusowie-Słowianie-Wikingowie u ujścia Wisty. Malbork: Muzeum Zamkowe w Malborku.

Urbańczyk, P. 2008. Trudne początki Polski. Wrocław: Wydawnictwo UW.

Vuorela, I., 1986. Palynological and historical evidence of slash-and burn cultivation in south Finland. In K-E. Behre, ed. Anthropogenic Indicators in Pollen Diagrams. Rotterdam: Balkema, pp. 53-64.

Wiszewski, P. 2010. Domus Bolezlai. Values and Social Identity in Dynastic Traditions of Medieval Poland (c. 966-1138). Leiden: Brill.

Wróblewski, W. 2006. Ziemie pruskie i jaćwieskie w okresie plemiennym (VII/VIII-XII/XIII w.). In W. Chudziak and S. Moździoch, eds. Stan $i$ potrzeby badań nad wczesnym średniowieczem w Polsce--15 lat później. Toruń: Wydawnictwo UMK, pp. 285-309.

Wyszomirski, S. (trans.) and Wenta, J. 2011. Piotr z Dusburga: Kronika ziemi pruskiej. Toruń: Wydawnictwo UMK.

\section{Figure captions}

Fig. 1. The castle at Malbork (Marienburg); view of south-western side from across the Nogat River. 
Fig. 2. A: Map of north Poland showing location of Vistula Delta; B: the traditionally assigned north-western border of Pomerelia/Pomesania (dotted line, aft. Powierski 2003: 119), and the Teutonic Order's commandery of Marienburg which transformed the borderland into a heartland (black line, aft. Długokęcki et al., 2004); C: main topographical features of the borderland landscape.

Fig 3. Simplified map of sites east of the Vistula with end phases dated by "Pomeranian ceramics" to the twelfth and thirteenth centuries (aft. Jagodziński 1997), indicating the Nogat did not function as a boundary during this time. Isolated surface finds and chronologically ambiguous sites have not been included.

Fig. 4. Pottery and iron spurs from excavations at Węgry (a-b) (aft. Trupinda 2004) compared with those found at Biała Góra (c-d). Not at same scale.

Fig. 5. Map of the macro-region between Malbork and Biala Góra showing a) the settlement pattern between the ninth and thirteenth centuries and b) the settlement pattern between the end of the thirteenth and fifteenth centuries (adapted from Haftka 1987 with Polish place names).

Fig. 6. Location and plan of the site of Biała Góra 3, with trenches marked by number and season of excavation.

Fig. 7. Example of a pit from the southern side of Biała Góra 3 (feature 94).

Fig. 8. Teutonic Order bracteates recovered from Biała Góra.

Fig. 9. Location of pollen cores sampled from the bounds of the former Marienburg commandery. Open circles - analzyed pollen sequences, black circles - pollen assessment only. 1) Parpary, 2) Benowo, 3) Stary Targ, 4) Gościszewo, 5) Malbork castle inner moat, 6) Koniecwałd, 7) Węgry, 8) Sztumskie Pole, 9) Sztum, 10) Pietrzwałd, 11) Kalwa.

Fig. 10. Selected taxa pollen percentage diagrams from a) Parpary, b) Benowo and c) Stary Targ. The grey silhouettes show values exaggerated x10. See figure 9 for location of individual pollen sequences.

Fig. 11. Plant macro-fossils from Biała Góra. 1. rye (Secale cereale) - carbonised caryopsis, 2. barley (Hordeum vulgare), 3. wheat (Triticum aestivum) - carbonised caryopsis, 4. millet (Panicum miliaceum) - carbonised caryopsis, 5. pea (Pisum sativum) - carbonised seed, 6. black bindweed (Fallopia convolvulus) - carbonised fruit, 7. common hazel (Corylus avellana) - fragment of charred nut, 8. raspberry (Rubus idaeus) - mineralised fruit stone, 9. cleavers (Galium aparine) - charred fruit (a. dorsal side, b. ventral side); scale base $-1 \mathrm{~mm}$.

Fig. 12. Examples of fish bone from key species found at Biała Góra: a) cod (Gadus morhua L.), b) sturgeon (Acipenser sp.), c) wels catfish (Siulurus glanis).

Fig. 13. Part of Caspar Henneberger's Map of Prussia showing the location of Zantyr (Zanther) in relation to the woods around Sztum, the Vistula, Nogat and Malbork (Margenburg). Edition reprinted in 1649 by Willem Janszoon Blaeu, Amsterdam, r.; $\mathrm{MZM} / \mathrm{DH} / 867$. 